\author{
Justyna Fudala \\ Uniwersytet Wrocławski \\ justyna.fudala@onet.pl
}

\title{
TEUMACZ WOBEC LITERATURY WULGARNEJ (NA PRZYKŁADZIE TWÓRCZOŚCI MIODRAGA BULATOVICIA)
}

DOI: http://dx.doi.org/10.12775/RP.2019.007

\begin{abstract}
Zarys treści: Styl autora oryginału wpływa na rodzaj technik translatorskich stosowanych przez tłumacza. Tłumacz literatury brzydkiej i wulgarnej może stanąć przed dylematem pominięcia w przekładzie pewnych elementów z tekstu wyjściowego, które wydają mu się zbyt kontrowersyjne i szokujące. Próbuje wówczas stworzyć bardziej łagodną wersję tekstu wyjściowego, świadomie deformując przekład. Celem artykułu jest przedstawienie elementów stylu serbskiego prozaika Miodraga Bulatovicia oraz wskazanie tendencji w tłumaczeniu literatury brzydkiej i wulgarnej na wybranych przykładach.
\end{abstract}

Słowa kluczowe: techniki tłumaczeniowe, wyzwania translatorskie, estetyka przekładu, literatura wulgarna, Miodrag Bulatović

\section{Wstęp}

Cormułowanie jednej uniwersalnej definicji sztuki jest bardzo trudne. ArUyści nie poruszają się w przestrzeni narzuconych ram, co powoduje, że zyskują duże poczucie wolności (Żyniewicz 2016: 127). Treści są prezentowane za pośrednictwem rozmaitych form, a częstą strategią wyrazu artystycznego stało się szokowanie i przekraczanie przyjętych norm społecznych. Mimo że odczuwamy lęk przed zjawiskami dziwnymi, jednocześnie ich pożądamy (Dittrich 2015: 13), odmienność jest bowiem dla współczesnego odbiorcy niezwykle ciekawa. W literaturze pięknej coraz częściej spotykamy się z kolei z wulgaryzacją języka. Jak zauważa Paulina Pycia, 
W obecnych czasach mamy jednak do czynienia z przyzwoleniem na posługiwanie się obscenicznym językiem, a w skrajnych przypadkach nawet $\mathrm{z}$ jego aprobatą, co wpływa między innymi na przekraczanie granic w różnych obszarach życia objętych tabu (Pycia 2012: 136).

Język stosowany przez autora oryginału jest poważnym wyzwaniem dla tłumacza, który powinien zachować w tłumaczeniu ten sam rejestr ${ }^{1}$ i właściwości języka. W niniejszym artykule skupimy się na technikach, które może stosować tłumacz wobec literatury uznawanej za brzydką i wulgarną. Rozważania zilustrujemy przykładami zaczerpniętymi z wybranych utworów serbskiego prozaika Miodraga Bulatovicia oraz z ich przekładów na język polski.

\section{Miodrag Bulatović i estetyka brzydoty}

Literacki debiut Miodraga Bulatovicia przypadł na lata 50. XX wieku, kiedy to opublikował on zbiór opowiadań Đavoli dolaze (polski tytuł Diabły nadchodza). Pierwsze utwory Bulatovicia zawierają swego rodzaju manifest programowy - pisarz pokazał świat składający się z obrazów ziemskiego piekła (wojny, walki, nienawiści, wszelkiej krzywdy), a winą za opisywane przez siebie nieszczęścia obarczył wyłącznie człowieka, który w jego interpretacji okazał się diabłem w ludzkiej skórze. Takie ujęcie świata spotkało się z ostrą krytyką (Palavestra 1972: 264), a Bulatoviciowi zarzucono szerzenie zła i pesymizmu oraz propagowanie szeroko rozumianej brzydoty. Autor czerpał z własnych doświadczeń, ponieważ w chwili swojego debiutu prowadził życie kloszarda oraz artysty - cygana (Bukwalt 2004: 65).

Bulatović został zapamiętany jako twórca o niebywałej wręcz wyobraźni, sięgający w swoich utworach do zaskakujących motywów i rozwiązań. Charakter jego działalności artystycznej trafnie podsumowuje Aldona Szukalska:

Znienawidzony przez jednych, przez innych uwielbiany, uwodził siłą swej żywiołowej wyobraźni, jednocześnie odpychając naturalizmem, pesymistyczną wizją świata, okrucieństwem i pornografią. Chęć szokowania, nieokiełznany temperament i niemieszczenie się w ramach socrealistycznego paradygmatu z czasem uczyniły go celem zaciekłych ataków krytyki literackiej oraz ofiarą społecznej nagonki (Szukalska 2013: 5).

${ }^{1}$ Rejestr rozumiemy jako „cechy specyficzne danego dyskursu wynikające z rodzaju relacji między rozmówcami, stopnia ich zażyłości, ich poziomu społeczno-kulturowego i omawianej tematyki" (za: Tomaszkiewicz 2004: 84). 
Większość spośród bohaterów wykreowanych przez pisarza jest psychicznie lub fizycznie upośledzona, a nierzadko są to ludzie po prostu przerażająco brzydcy. Często są to osoby z marginesu, udręczeni schizofrenicy lub niespełnieni artyści znajdujący się w stanie upadku i degeneracji (Bukwalt 2006: 79). Chorobliwie zdeformowany świat bohaterów jest przedstawiony w sposób karykaturalny i groteskowy. Podobnie wygląda kwestia doboru tematyki poruszanej w tej prozie, która daleko odbiega od norm zwyczajowych i społecznych. Można odnieść wrażenie, że pisarz czerpał z założeń estetyki przesady - z czasów ciemnych wieków Europy między VII a X stuleciem, naznaczonych zaniedbywaniem miast, upadkiem rolnictwa, niszczeniem pozostałości wcześniejszych cywilizacji i ogólnym zdziczeniem. Artyści cenili wówczas wyolbrzymienie i przesadę, a świat pokazywali jako ciemną i ponurą gęstwinę zamieszkiwaną przez potwory (Eco 2007: 111-112). Podobnie wygląda przecież świat Bulatovicia - zdeformowane postacie i groteskowe przerysowania możemy spotkać w większości jego utworów.

Motywem szczególnie charakterystycznym dla tematyki podejmowanej przez Miodraga Bulatovicia jest zło i jego wpływ na kształtowanie się postaw ludzkich. Waldemar Chołodowski postuluje, aby przyczyn tych zainteresowań szukać w doświadczeniach osobistych, związanych z czasami okupacji, na które przypadło dzieciństwo i młodość autora (Chołodowski 1984: 13). Radovan Vučković stwierdza wręcz, że twórczość Bulatovicia, tak wyraźnie naznaczona wojennym piętnem, jest najlepszą propozycją dla świata zmienionego przez wojnę:

Tak powstawała proza nowoczesnego typu u nas po tej wojnie: proza, w której krańcowy cynizm i sarkazm stykają się z sentymentalną patetyką; bezlitośnie krytyczna analiza człowieka z liryczną elegią; naturalistyczna groteska z symboliczno-romantycznym przywoływaniem jakiejś transcendentnej funkcji, która znikła w bezkresnej przestrzeni i czasie (Vučković 1973: 650).

Równie wyraziste są motywy erotyczne. Pokazywanie seksualności (niekiedy przekraczającej granicę pornografii i dewiacji) służy Bulatoviciovi jako środek wyśmiania współczesnego mu świata. Pisarz udowadnia, że dążenie do zaspokojenia własnych potrzeb może pozbawić człowieka rozsądku i sprawić, że straci on kontrolę nad własnym życiem. Bulatović zdecydował się na pokazywanie seksu zdegradowanego, stanowiącego wytwór współczesnych mu czasów (Chołodowski 1986: 233-235), a poprzez sceny rozpusty próbował obnażyć podstawowy antyhumanizm mitologii wojny (Ilić 1986: 263). 
Wyzwania translatorskie wynikają z estetyki danego utworu. Styl pisarza determinuje charakter pracy tłumacza, który język wulgarny powinien tłumaczyć wulgarnie, obrazy brzydkie pozostawiać brzydkimi, elementy szokujące zaś zachowywać w ich pełnym wymiarze. Miodrag Bulatović nie tylko sięgał do trudnych tematów, ale również niejednokrotnie przeprowadzał zróżnicowane eksperymenty formalne (Szukalska 2013: 19), które dodatkowo wpływają na charakter pracy tłumacza. W kolejnym podrozdziale przyjrzymy się, jakie techniki zastosowali tłumacze, aby w odpowiedni sposób zaprezentować polskim czytelnikom tę skomplikowaną i różnorodną literaturę.

\section{Tłumaczenie literatury brzydkiej i wulgarnej}

Mimo że każdy tłumacz powinien być świadomy roli pośrednika, którą przyjmuje na siebie w chwili rozpoczęcia pracy nad przełożeniem danego utworu literackiego, niejednokrotnie bardzo trudne okazuje się pozostanie wiernym stylistyce proponowanej przez autora oryginału. Kwestia stylu i stylistyki jest szczególnie problematyczna $\mathrm{w}$ utworach zawierających elementy światopoglądu znacząco odbiegające od tych, które wyznaje tłumacz. Między innymi od profesjonalizmu translatora zależy, czy będzie on w stanie przygotować tłumaczenie funkcjonalnie równoważne $\mathrm{z}$ tekstem wyjściowym. Czasami trudno oprzeć się pokusie wygładzenia języka czy też upiększenia niektórych treści, jak bowiem zaznacza Bożena Rejakowa, nie jesteśmy w stanie udzielić jednoznacznej odpowiedzi na pytanie, czy możliwe jest wyznaczenie granic inwencji twórczej w tłumaczeniu artystycznym (Rejakowa 1994: 11). W odczuciu autorki niniejszego opracowania granicę twórczego podejścia tłumacza do utworu wyznacza funkcjonalność tegoż, ponieważ utwór przetłumaczony powinien wywołać wśród jego odbiorców w kulturze docelowej asocjacje zbieżne z tymi, które spowodował oryginał wśród jego czytelników.

Niemniej, każde tłumaczenie jest formą interpretacji i, jak podkreśla Elżbieta Skibińska, nigdy nie istnieje w izolacji, może bowiem świadczyć o konkretnych postawach społeczności, której przedstawicielem jest tłumacz (Skibińska 1999: 9-12). Tłumacz jest wszakże również odbiorcą, czytelnikiem i interpretatorem tłumaczonego tekstu, a zatem jego doświadczenia emocjonalno-estetyczne mają wpływ na ostateczny kształt przekładu. Każdego człowieka cechuje subiektywna wrażliwość na istotę tekstu, czyli na walory dzieła literackiego (Krzysztofiak 1999: 41). Maria Krzysztofiak przypomina jednak, że: 
Styl artystyczny, właściwy dziełom literackim, jeden z wielu stylów funkcjonalnych, przejawia się poprzez określone właściwości, np. indywidualnego stylu autora lub zbiorowego stylu epoki. Styl to, jak uważają teoretycy literatury, szczególny sposób nadawania kształtu tworzywu językowemu, to organizacja brzmieniowa i instrumentacja języka, wreszcie styl to także repertuar świadomie stosowanych znaków kulturowych (Krzysztofiak 1999: 91),

i w miarę możliwości w tłumaczeniu elementów tych nie należy wymieniać na inne, a jedynie „dostosować je do norm stylistycznych właściwych dla kultury docelowej przekładu” (Krzysztofiak 1999: 92). Zastanówmy się zatem, jakie dylematy translacyjne mogą pojawić się podczas tłumaczenia literatury szeroko pojmowanej jako brzydka i wulgarna. Przykłady analizowane w dalszej części pracy pochodzą z trzech utworów Miodraga Bulatovicia - z powieści Heroj na magarcu i Ljudi sa četiri prsta oraz z opowiadania Nema povratka, a także z tłumaczeń tych utworów na język polski².

Pełen odbiór przekładu może zostać zakłócony przez rozmaite deformacje, które - często nieświadomie - wprowadza tłumacz ${ }^{3}$. Czasami są one wynikiem celowego dostosowania tekstu do możliwości odbiorcy wywodzącego się z innego kręgu kulturowego i posiadającego inne kompetencje niż rodzimi użytkownicy języka. Nieprzemyślane modyfikacje prowadzą jednak do zaburzeń w odbiorze utworu i zakłócają proces komunikacji pomiędzy autorem oryginału a odbiorcą przekładu. W przypadku tłumaczenia literatury uznawanej za brzydką i wulgarną w pierwszej kolejności tłumacz może dążyć do uszlachetniania tekstu (albo przeciwnie - do jego nadmiernej wulgaryzacji), a także zubożyć go ilościowo i jakościowo.

Bardzo ważnym elementem charakterystycznego stylu Bulatovicia jest język - mocny w przekazie, dosadny, nierzadko obsceniczny, perwersyjny i przepełniony wulgaryzmami. Tłumacz może ulec pokusie wyrażenia własnych odczuć estetycznych. Będzie wówczas wybierał subtelniejsze określe-

2 Wybór tych konkretnych utworów został podyktowany chęcią zgromadzenia przykładów ze wszystkich etapów twórczości Miodraga Bulatovicia, ponieważ w pewnym stopniu różnią się one podejściem pisarza do prezentowanej tematyki i motywów.

${ }^{3}$ Francuski teoretyk przekładu Antoine Berman wymienia aż 12 tendencji deformujących przekład. Są to: racjonalizacja, objaśnianie, wydłużanie, uszlachetnianie lub wulgaryzacja, zubażanie jakościowe i ilościowe, niszczenie rytmu, niszczenie ukrytych sieci znaczeniowych, niszczenie systematyczności języka, niszczenie elementów rodzimych lub egzotyzacja, niszczenie zwrotów idiomatycznych oraz zacieranie superpozycji języków (Berman 2009: 253). 
nia o bardziej neutralnym nacechowaniu. Zaprezentuje elegantszą formę, co paradoksalnie należałoby jednak uznać za zubożenie jakościowe, ponieważ wulgaryzacja języka była jednym z celowych zabiegów zastosowanych przez Bulatovicia i spełnia w tej twórczości określone funkcje. Rezygnowanie z wulgaryzmów i brzydkich opisów będzie również zubożeniem ilościowym, pozbawieniem tekstu jego istotnych elementów. Spójrzmy na poniższy przykład:

1) Prekrsti ruke na leđima i stade žustro koračati između kauča i pisaćeg stola. Major je glodao lulicu i posmatrao ga. „Sigurno ona albanska kurvetina?” reče pukovnik kao za sebe: „Onaj gad prljavi!” (Bulatović 1967: 15).

Fragment zawiera opis reakcji bohatera na wiadomość, że zostanie ojcem (eufemistycznie ujmując - nie jest on tym faktem zachwycony). W bardzo emocjonalnej wypowiedzi matkę swojego nienarodzonego dziecka wyzywa określeniem albanska kurvetina. W polskim przekładzie fragment wygląda następująco:

1) Allegretti założył ręce na plecy i zaczął szybko chodzić pomiędzy kanapą i biurkiem. Major przyglądał mu się gryząc fajeczkę. - Pewnie to albańskie kurwiszcze? - powiedział pułkownik jakby do siebie. - Ta plugawa żmija! (Bulatović 1994: 32)

Używanie wulgaryzmów wyraźnie wpływa na negatywny stosunek odbiorcy do nadawcy komunikatu, a na takim właśnie efekcie zależało autorowi. Co więcej, mocno zwulgaryzowany język odzwierciedla negatywne stanowisko Bulatovicia wobec wojny i okupacji - pisarz jest daleki od ich gloryfikowania. Tłumacz zachowuje charakter komunikatu i nie próbuje poddać go eufemizacji. W tłumaczeniu zostały utrwalone istotne cechy rejestru języka zastosowanego przez Bulatovicia. Co ciekawe, kobieta w tekście źródłowym jest określona jako gad prljavi (dosłownie - brudny gad), tymczasem tłumacz zaproponował odpowiednik plugawa żmija, dostosowany do świadomości polskich odbiorców, który trafnie pozwala im zinterpretować relacje panujące między przyszłymi rodzicami.

W podobnym tonie, pod względem zachowania poziomu wulgarności, utrzymane są kolejne fragmenty:

2) Otkad kurve za nas navijaju ne ide nam najbolje! (Bulatović 1967: 16)

2) Odkąd kurwy nam kibicują, coraz gorzej z nami! (Bulatović 1994: 33) 
3) Za kurvom i za tramvajem nikad ne trči. Noge čuvaj za bežanje, emigrant si! (Bulatović 1998: 21)

3) Za kurwa i za tramwajem nigdy się nie biega. Nogi zachowaj do ucieczki, jesteś emigrantem! (Bulatović 1983: 16) ${ }^{4}$

W obu przypadkach leksem kurva/kurwa zastosowany został w celu pogardliwego określenia prostytutki. Podobnie jak w pierwszym przykładzie, tłumacz podąża za stylistyką kreowaną przez autora oryginału, decydując się na obcesowy i wulgarny język.

Nieco odmienny zabieg tłumacz zastosował w przypadku poniższego fragmentu:

4) Ja se međutim ne slažem. Osvojiti srca pesnika, artista, klovnova, lopuža, ološi, šljama, dna, srca žena, kurvi uopšte - za mene je najdragocenija pobeda (Bulatović 1967: 16).

4) Ja się natomiast nie zgadzam. Podbićserce kurwy to dla mnie najrzadsze i najcenniejsze zwycięstwo (Bulatović 1994: 33).

Tekst tłumaczenia jest wyraźnie krótszy, przez co skondensowany jedynie na treści wulgarnej - na podbiciu serca kurwy. Tymczasem w oryginale bohater wymienia zdecydowanie więcej postaci (między innymi poetów, artystów czy kobiety w ogóle). Tłumacz skupia się na wulgarnym elemencie komunikatu, dysfemizując przekaz, upraszczając go i skracając. Być może w tym fragmencie chciał zrekompensować pewne złagodzenia, które są widoczne w innych partiach tekstu.

Z zabiegiem przeciwnym mamy do czynienia w kolejnych przykładach. Wyraźne jest w nich zjawisko stopniowania poziomu wulgarności. Tymczasem zastosowanie mniej wulgarnej formy może doprowadzić do zmiany charakterystyki bohatera, wyciszenia negatywnych emocji i agresji. Polski czytelnik zobaczy obraz nieco odmienny niż czytelnik oryginału, może go inaczej zinterpretować i wartościować niezgodnie z zamierzeniem autora tekstu wyjściowego.

${ }^{4}$ Wnikliwy czytelnik może zauważyć, że polskie tłumaczenie zostało wydane wcześniej niż utwór tłumaczony - pierwsze wydanie powieści Ljudi sa četiri prsta pochodzi z roku 1975. Autorka niniejszego opracowania skorzystała z antologii utworów Bulatovicia wydanej w roku 1998, w której analizowany utwór został zamieszczony. 
5) Ko jebe Zirndorf i njegove ogavne špijune svih, ali pretežno istočnoevropskih vrsta! Pas im mater! Legitimacija i pasoša, i bez njihovih, imam koliko hoćeš! (Bulatović 1998: 22)

5) Niech szlag trafi Zirndorf i jego plugawych szpiclów wszelkiej, a przeważnie wschodnioeuropejskiej maści! Pies im mordę lizat! Legitymacji i paszportów mam, ile zechcesz, obejdzie się bez łaski! (Bulatović 1983: 16-17)

Pierwsza z zaznaczonych fraz ko jebe została przetłumaczona jako niech szlag trafi - serbskie wyrażenie korzysta z produktywności czasownika jebati, który pozwala na wyrażenie szerokiego spektrum wulgarności. Z kolei propozycja polskiego tłumacza została utrzymana raczej w rejestrze kolokwialnym lub pospolitym, jednak nie tak wulgarnym jak oryginał. Jeszcze większą różnicę $\mathrm{w}$ poziomie wulgarności widać $\mathrm{w}$ parze przykładów pas im mater (które jest skróconą formą od obelgi jebao im / vam pas mater) i pies im mordę lizał. Jedyna równoważność pomiędzy tymi odpowiednikami sprowadza się w zasadzie do wykorzystania w nich wizerunku psa, użyty tu bowiem polski związek frazeologiczny ma nacechowanie pospolite lub pejoratywne, zdecydowanie lekceważące, jednak nie wulgarne. Podobną gradację widzimy poniżej:

6) Vaše vas olovo čeka, desetak naboja za mašinski Walther, nož nalik na onaj iz Jasenovca, što je ostao u Kazimirovom vratu! Pizde pijane, takva li ste zaštitnica svom Budaku! (Bulatović 1998: 205)

6) Wasz ołów na was czeka, dziesięć nabojów do Waltera, nóż podobny do tamtego z Jasenovca, który został w szyi Kazimira! Gnidy pijane, ładna z was ochrona dla Budaka! (Bulatović 1983: 169)

Serbskie pizde pijane i polskie gnidy pijane mają inne nacechowanie. Tłumaczenie zaprezentowanego fragmentu jest dość kłopotliwe, ponieważ stanowi on wyraz charakterystycznych bałkańskich kodów kulturowych, w których frekwencyjność wulgaryzmów jest zdecydowanie większa niż w języku polskim. Kontekst kulturowy powinien mieć wpływ na decyzje tłumacza $\mathrm{w}$ powyższym fragmencie nie zdecydował się on na dosłowne przeniesienie w postaci zwrotu pijane pizdy, ponieważ w języku polskim użycie formy w tej postaci jest preferowane dla rodzaju żeńskiego, w serbskim zaś stosowane jest również dla rodzaju męskiego. Tłumacz przeprowadził zatem eufemizację, podobnie jak i w kolejnym fragmencie:

7) Napravio me, kažu, Srbin s Mađaricom, ili Mađar s Rumunkom, što je isto u onom panonskom burdelju, zvanom Vojvodina (Bulatović 1998: 50). 
7) Spłodzit mnie podobno Serb z Węgierką czy Węgier z Rumunką, co w burdelu zwanym Wojwodiną na jedno wychodzi (Bulatović 1983: 42).

Kolokwialne wyrażenie napravio me można by oddać równie kolokwialnym zrobił mnie, tłumacz zdecydował się jednak na formę literacką spłodził mnie. Doprowadziło to do zmian w idiolekcie bohatera, a co za tym idzie - do odmiennego postrzegania go przez polskiego czytelnika.

$\mathrm{Z}$ interesującym zabiegiem mamy do czynienia w poniższej parze przykładów:

8) Ješćeš polupečeno, krvavo meso. Piti žestoka, muška pića, ili šta stigneš. Jahaćeš, kao i ja, skupe i besne, švapske mačke (Bulatović 1998: 30).

8) Będziesz jadł ledwie przysmażone, krwiste mięso. Będziesz pił mocne męskie napoje albo co się da. Będziesz chędożyt, tak jak ja, drogie i wściekłe szwabskie kocice (Bulatović 1983: 24).

W oryginale czasownik jahati służy wyrażeniu czynności seksualnych, podobnie zresztą jak polskie chędożyć. Wyraźna jest jednak różnica w nacechowaniu emocjonalnym tych leksemów, propozycja polskiego tłumacza wywołuje bowiem wśród odbiorców raczej lekkie rozbawienie, odmiennie niż założenie autora oryginału. Zastosowanie takiego ekwiwalentu może co prawda wynikać z okresu, w którym tłumaczenie powstało (lata 80. ubiegłego stulecia), co nie zmienia faktu, że wśród współczesnych użytkowników języka funkcjonuje wiele określeń bardziej adekwatnie wyrażających pospolicie czy też wulgarnie nacechowaną seksualność.

Miodrag Bulatović pokazywał w swoich utworach obrazy odbiegające od ogólnie przyjętych norm społecznych, dziwne i groteskowe, wykorzystując niewyczerpane wręcz pokłady wyobraźni. Sięgał do trudnych tematów i kreował nieoczywistych bohaterów, jednak interpretację świata przedstawionego pozostawiał czytelnikom. Tłumacz powinien stworzyć swoim odbiorcom możliwość odczytywania aluzji umieszczonych w tekście oryginału, aby nie pozbawiać ich przyjemności i satysfakcji wynikającej z własnej analizy czytelniczej. Nadmierne objaśnianie i racjonalizacja mogą ponadto wpłynąć na wydłużenie tekstu, co również należy uznać za deformacje wprowadzane do tłumaczenia literatury wulgarnej.

W poniższym fragmencie widzimy opis spalającego się pnia, który jest przykładem fascynacji autora ogniem i jego niszczycielską siłą. Bulatović przedstawił proces spalania bardzo szczegółowo i poetycko. 
9) Na put, pred njega, skotrlja se panjina, gotovo klada, najobičnija krlja dugih i trulih žila. Čitav roj mrava, čitavo gmizavo klupko bežalo je iz trupine i pištalo, i zaudaralo, i peklo oči. Trulina je gorela, dimila, kotrljala se putem (Bulatović 1958: 14).

Ponieważ plastyczne opisy natury są jedną z charakterystycznych cech twórczości serbskiego prozaika, łłumacz musiał dołożyć wszelkich starań, aby jego tekst również pozwolił czytelnikom na poczucie zapachu spalenizny i piekącego żaru w oczach. Przekład analizowanego fragmentu przedstawia się następująco:

9) Na drogę, przed jego stopy, stoczył się pień, kłoda, najzwyklejsza masa długich i zbutwiałych korzeni. Potężny rój mrówek. Calutka pełzająca plątanina uciekała z pnia, piszczała, cuchnęła i piekła w oczy. Stęchlizna płonęła, dymiła i toczyła się drogą (Fudala 2015: 68) .

Bulatović kreuje świat przedstawiony z perspektywy zwykłych ludzi i trudów ich życia. Jego bohaterowie mają liczne wady, przeważnie związane z fizycznymi ułomnościami (deformacje ciała, odbieganie od przyjętego kanonu urody). Autor nie boi się pisać o ich problemach. W poniższym fragmencie tak opisuje ofiary wojny:

10) Mi smo (...). Crne majke što se kao insekti miču za malim crnogorskim četama, noseći u torbama hranu i obuću. Osramoćene žene i ružne sestre što na raskrsnicama čekaju braću s ponudama i darovima. Onemoćali, podetinjali i slinavi starci što sanjare o slavi i junaštvu svojih unuka kojih odavno nema. (...) Insekti tvrdokrilci, zmije i gušterovi - sve nadanje ljudi u nesreći (Bulatović 1958: 8).

W przekładzie treść jest równie przygnębiająca i wywołuje negatywne emocje. Tłumacz próbuje podążać za estetyką zaproponowaną przez serbskiego prozaika:

10) Są wśród nas (...) Kobiety w żałobie, które niczym robactwo wloką się za małymi czarnogórskimi oddziałami, niosąc w torbach jedzenie i buty. Pohańbione i szpetne siostry, które na rozstajach dróg ofiarowują braciom swoje ciała. Bez-

${ }_{5}$ Tłumaczenie utworu Nema povratka zostało dokonane przez autorkę niniejszego opracowania na potrzeby pracy magisterskiej, J. Fudala, Opowiadanie Nema povratka Miodraga Bulatovicia - tłumaczenie i próba monografii, nieopublikowana praca magisterska, Wrocław 2015. 
silni, zdziecinniali i śliniący się starcy, marzący o bohaterskiej sławie swoich dawno zmarłych wnuków. Jesteśmy (...). Chrząszczami, wężami i jaszczurkami - jedyną nadzieją ludzkości pogrążonej w nieszczęściu (Fudala 2015: 61).

W tej mocno naturalistycznej wizji ludzie zostali porównani do robactwa i zwierząt powszechnie uważanych za odpychające (takich jak węże i jaszczurki). Odrazą napawa ponadto bardzo realistyczny obraz ludzi starszych. W interpretacji Bulatovicia charakteryzują się oni zdziecinnieniem i bezsilnością, która przejawia się również w fizycznych niedoskonałościach (w tym fragmencie świadczy o tym cieknąca $z$ ust ślina). Tłumacz unika objaśniania aluzji i niedopowiedzeń, aby właściwą interpretację przedstawionego obrazu pozostawić czytelnikowi. Przykładowo, o ofiarach gwałtu pisze się osramoćene žene i ružne sestre, w przekładzie zaś są to pohańbione i szpetne siostry.

Bulatović często włącza w swoje utwory kontrowersyjne opisy. O dzieciach dotkniętych wojną pisze następująco:

11) Nisu ga čudile čak ni one dugačke merdevine, prislonjene uza zid zgradurine, ni redovi starih dečjih kolica, napunjenih nagaravljenim parčićima stakla, ni starčić sa sviralom što je čučao u kruni lipovoj. Video je gomilu zakržljale, gušave, ćelave i vesele dece izbočenih trbušića i tankih ruku koja su se s mukom vukla oko plota, i vodila belo jarence na dretvici (Bulatović 1958: 12-13).

Tłumaczenie na język polski wygląda następująco:

11) Nie dziwiły go nawet długaśne drabiny oparte o ścianę gmaszyska. Ani rzędy starych, dziecięcych wózków, napełnionych osmalonymi sadzą kawałkami szkła. Nawet staruszek z fujarką, co przysiadł w lipowej koronie. Widział gromadkę niedorozwiniętych, łysych, ale wesołych dzieci ze zdeformowanymi szyjami, o wydętych brzuszkach i wiotkich rękach, które z trudem wlekły się koło płotu, prowadząc na postronku białego koziołka (Fudala 2015: 67).

Mroczną atmosferę udało się autorowi wykreować między innymi dzięki posługiwaniu się odpowiednimi środkami stylistycznymi. W powyższym przykładzie widzimy augmentativa (zgradurina) oraz deminutiva (starčić, trbušić, jarence). Tłumacz również zachowuje je w tekście (odpowiednio: gmaszysko, staruszek, brzuszki, koziołek). Wyzwaniem dla tłumacza stał się z kolei serbski przymiotnik gušav, który określa osobę zmagającą się z powiększeniem tarczycy, objawiającym się widocznymi na szyi guzami. W języku polskim konieczne stało się opisowe oddanie zjawiska - dzieci ze zde- 
formowanymi szyjami. Co prawda funkcjonuje słownikowe określenie danej jednostki chorobowej - wole tarczycy, jednak termin ten ma charakter oficjalny, medyczny i nie wpisuje się w kontekst opowiadania. Propozycja wybrana przez tłumacza nie pozbawia tekstu mrocznego klimatu wykreowanego przez autora $\mathrm{w}$ oryginale.

Wśród motywów wykorzystywanych przez Bulatovicia można dostrzec wyraźną fascynację symboliką falliczną. Opisy męskiego przyrodzenia są w głównej mierze elementem literackiej prowokacji oraz groteskowej gry z czytelnikiem (Szukalska 2013: 131-134). W poniższym fragmencie oprócz nawiązań do wizerunku fallusa (balkanski kolac / bałkański kołek) przedstawiony został także motyw gwałtu, często powtarzany przez Bulatovicia:

12) Čime je Adonaj stvorio svet, Frumkine? pitao je Marković nabijajući ga pod sam rep Angeliki. (...) Jankelović je vrhovima grešnih prstiju pridržavao donju vilicu i usnu, ćutao, te je mršava, smežurana i pijana Angelika, primajući balkanski kolac u svoju drugu i nevinu klasu, meketala (Bulatović 1998: 76-77).

12) Czym Adonai stworzył świat? - spytał Marković wbijając go tuż pod ogon Angeliki. (...) Jankielewicz czubkami grzesznych palców obejmował dolną szczękę i wargę. Milczał. Pomarszczona i pijana Angelika, przyjmując bałkański kołek do swojej drugiej, niewinnej klasy, beczała jak koza (Bulatović 1983: 65-66).

Tłumaczenie prezentuje estetykę zgodną z założeniem autora oryginału. Zmetaforyzowany obraz gwałtu jest równie wulgarny, co w tekście wyjściowym.

Groteskową brzydotę stylu Miodraga Bulatovicia obrazuje z kolei kolejny przykład, zawierający opis płonącej lalki:

13) Do njegovih nogu dokotrlja se dečja igračka. Lutki je gorela glava. Do njega se dokotrlja još jedna lutka, prekršenog grla, bez ruke i sa zapaljenom haljinom (Bulatović 1958: 18).

W przekładzie scena wygląda następująco:

13) Do jego nóg przyturlała się dziecięca zabawka. Lalce płonęła głowa. Doturlała się jeszcze jedna lalka z poderżniętym gardłem, bez rąk i w podpalonej sukience (Fudala 2015: 72).

Dzięki zastosowaniu czasowników (doturlać się, przyturlać się, poderżnąć) tłumaczowi udało się zachować dynamizm opisywanych wydarzeń. 
Wizerunek płonącej lalki z poderżniętym gardłem budzi grozę i wpływa na wyobraźnię odbiorcy, co odzwierciedla brutalizm zawarty w oryginale oraz potęguje wrażenie wszechobecnego nieszczęścia.

\section{Przekład literatury brzydkiej i wulgarnej - podsumowanie}

Miodrag Bulatović to pisarz niezwykły, którego styl można pokochać lub na trwałe znienawidzić. Styl ten śmiało można określić jako groteskową syntezę brzydoty i piękna oraz wzniosłości i trywialności (Bukwalt 2004: 72). W swoich kreacjach literackich Bulatović nigdy nie bał się prezentować motywów niecodziennych, przez wielu uważanych za odpychające i odrażające. Najbardziej charakterystyczną cechą twórczości tego autora jest stosowany przez niego język - mroczny i jednocześnie magiczny, wulgarny, prezentujący obrazy przesycone erotyzmem i pornografią, ale jednocześnie bardzo plastyczny, opisujący świat przedstawiony z malarską dokładnością. O Bulatoviciu śmiało można powiedzieć, że to pisarz stylowy, ponieważ wykreował własną estetykę, którą możemy nazywać estetyką brzydoty. A co najważniejsze - pozostał jej wierny we wszystkich swoich utworach.

Nie mamy wątpliwości, że styl i język, którym posługuje się autor oryginału, wpływają na pracę tłumacza, determinują rodzaj zabiegów, które musi on zastosować6. Tłumacz powinien dążyć do poszanowania wszelkich właściwości tekstu wyjściowego, a zatem elementy wulgarne i brzydkie oddawać w ich pełnej kontrowersyjności. Przekład utworów zawierających elementy wulgarne jest szczególnie trudny, ponieważ wymaga przekraczania istniejących w wielu społecznościach barier (Pycia 2012: 147). Może to być poważne wyzwanie, gdyż, chcąc tego lub nie, każdy tłumacz pozostaje pod wpływem własnego światopoglądu, który może być daleki od przedstawianego w utworze oryginalnym. Wulgarność może zatem ulegać pewnym subiektywnym interpretacjom. Tłumacz musi jednak pamiętać, że jest jedynie pośrednikiem, bez którego co prawda niemożliwe byłoby spotkanie autora oryginału i czytelnika przekładu, nie może on jednakże rościć sobie prawa do ingerencji w treść utworu, nad którym pracuje. Można odnieść wrażenie, że polscy tłumacze utworów Bulatovicia ostrożnie podchodzą do kwestii wulgarnego języka. Prawdopodobnie ta swego rodzaju zachowawczość wynika jednak

${ }^{6}$ Szerzej na temat wyzwań translatorskich w tłumaczenia opowiadań Bulatovicia zob. Fudala 2017. 
z faktu, że tłumaczenia powieści powstały w latach 70. i 80. ubiegłego stulecia, kiedy to działalność artystyczna podlegała cenzurze.

Brutalizacja treści i wulgaryzacja języka, o ile nie jest jedynie próbą przyciągnięcia uwagi odbiorcy i zaszokowania go, powinna spełniać pewien ściśle określony cel. W przypadku utworów Miodraga Bulatovicia środki te służą wyrażeniu powojennej traumy. Bardzo istotne jest, że Bulatović nie próbował narzucić czytelnikowi własnego światopoglądu i zawsze pozostawiał mu możliwość interpretacji oraz szerokiej refleksji towarzyszącej lekturze. Takie samo zadanie stoi przed tłumaczem, który to, co wulgarne, powinien pozostawić wulgarnym, a możliwość interpretacji i oceny przekazać czytelnikom. Tłumacz utworów Miodraga Bulatovicia musi ponadto wykazać się umiejętnością przenoszenia groteskowo przerysowanych i kontrowersyjnych obrazów, obscenicznych opisów i wulgarnego języka, które składają się na piękno literackiej brzydoty, prezentowanej przez serbskiego prozaika.

\section{Literatura}

Berman A., 2009, Przekład jako doświadczenie obcego, [w:] Współczesne teorie przekładu. Antologia, P. Bukowski, M. Heydel (red.), Kraków, s. $249-264$.

Bukwalt M., 2004, Groteskowy obraz świata w opowiadaniu „Tyrania” Miodraga Bulatovicia, „Slavica Wratislaviensia”, CXXXI, s. 65-76.

Bukwalt M., 2006, Motyw szaleństwa w opowiadaniu „Zatrzymaj się, Dunaju” Miodraga Bulatovicia, „Slavica Wratislaviensia”, CXXXIX, s. 79-86.

Bulatović M., 1994, Bohater na ośle, przeł. D. Ćirlić-Straszyńska, Warszawa.

Bulatović M., 1967, Heroj na magarcu, Cetinje.

Bulatović M., 1998, Ljudi sa četiri prsta. Peti prst. Antologija, Beograd.

Bulatović M., 1983, Ludzie o czterech palcach, przeł. D. Ćirlić-Straszyńska, Warszawa.

Bulatović M., 1958, Vuk i zvono. Povesti o ogniu, zatočenicima i još nekim ljudima, Beograd.

Chołodowski W., 1984, Miodrag Bulatović, „Literatura na Świecie”, 9, s. 12-14 .

Chołodowski W., 1986, O Bulatoviciu, „Literatura na Świecie”, 1, s. 230-249.

Dittrich W., 2015, Wstręt, obrzydzenie, fascynacja. Dziwoląg i jego postrzeganie w XX wieku, [w:] Wstręt i obrzydzenie, W. Dittrich, M. Hybiak, M. Wirski, M. Zegarlińska (red.), Gdańsk, s. 13-20.

Eco U., 2007, Historia brzydoty, Poznań. 
Fudala J., 2015, Opowiadanie „Nema povratka” Miodraga Bulatovicia - tłumaczenie i próba monografii, nieopublikowana praca magisterska, Wrocław.

Fudala J., 2017, Opowiadanie „Nema povratka” Miodraga Bulatovicia - tłumacz jako pośrednik między literaturą serbską a polską, „Rocznik Przekładoznawczy. Studia nad teorią, praktyką i dydaktyką przekładu”, 12, s. 117-129.

Ilić A., 1986, Stworzyć noc, „Literatura na Świecie”, 1(174), s. 250-279.

Krzysztofiak M., 1999, Przekład literacki a translatologia, Poznań.

Palavestra P., 1972, Posleratna srpska književnost 1940-1970, Beograd.

Pycia P., 2012, Przekraczając granice. Problem przekładu wulgaryzmów i przekleństw, „Przekłady Literatur Słowiańskich”, 1, s. 135-148.

Rejakowa B., 1994, Mechanizmy językowe w przekładzie związków frazeologicznych na materiale języka polskiego i słowackiego, Lublin.

Skibińska E., 1999, Przekład a kultura. Elementy kulturowe we francuskich tłumaczeniach Pana Tadeusza, Wrocław.

Szukalska A., 2013, Problematyka wizualizacji w prozie Miodraga Bulatovicia, Kraków.

Tomaszkiewicz T., 2004, Terminologia tłumaczenia, Poznań.

Vučković R., 1973, Tragikomiczny świat marionetek Miodraga Bulatovicia, „Literatura na Świecie”, 8, s. 648-671.

Żyniewicz K., 2016, Sztuka jako narzędzie badania granic. Pozaartystyczne wnioski płynące z artystycznych eksperymentów, [w:] A fe! Społeczno-kulturowe konteksty wstrętu i obrzydliwości, A. Drzał-Sierocka, M. Kowalewska (red.), Gdańsk, s. 125-136.

\section{Słowniki}

Grochowski M., 2002, Słownik polskich przekleństw i wulgaryzmów, Warszawa.

Imami P., 2007, Beogradski frajerski rečnik, Beograd.

Matešić J., 1982, Frazeološki rječnik hrvatskoga ili srpskog jezika, Zagreb.

Menac A. (red.), 2003, Hrvatski frazeološki rječnik, Zagreb.

Menac A. (red.), 1986, Hrvatskosrpsko-poljski frazeološki rječnik, Zagreb.

Müldner-Nieckowski P., 2003, Wielki słownik frazeologiczny języka polskiego, Warszawa.

Otašević Đ., 2007, Mali srpski frazeološki rečnik, Beograd.

Rečnik srpskoga jezika, Matica srpska, 2011, Novi Sad.

Skorupka S., 2002, Słownik frazeologiczny języka polskiego, Warszawa.

Šipka D., 2011, Rečnik opscenih reči i izraza, Novi Sad-Beograd. 


\section{Translation of vulgar literature (based on works of Miodrag Bulatović) Summary}

The author's style influences translation techniques applied by the translator. The translator of ugly and vulgar literature often tries to ignore certain controversial fragments as they may seem too shocking. The translator tries to create a subtler version and consciously deforms the translation. The aim of this article is to indicate trends deforming the translation of ugly and vulgar literature based on selected works of Miodrag Bulatović.

Keywords: translation techniques, challenges for the translator, stylistics of translation, vulgar literature, Miodrag Bulatović

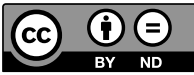

